\title{
Providing clinical evidence under the MDR 2017/745 - new challenges for manufacturers in medical device industry
}

\author{
Elena Ivanovska ${ }^{1^{*}}$, Jasmina Tonic Ribarska ${ }^{2}$, Jelena Lazova ${ }^{1}$, \\ Nada Popstefanova ${ }^{1}$, Marija Davcheva Jovanoska ${ }^{1}$, \\ Suzana Trajkovic Jolevska ${ }^{2}$ \\ ${ }^{1}$ Pharmaceutical Chemical Cosmetic Industry ALKALOID AD Skopje, \\ Skopje, Republic of North Macedonia \\ ${ }^{2}$ Faculty of Pharmacy, University „Ss Cyril and Methodius”, Skopje, \\ Republic of North Macedonia \\ *Corresponding author: Dr Elena Ivanovska, \\ e-mail: eivanovska@alkaloid.com.mk
}

\section{Summary}

Providing necessary clinical evidence throughout the systems for Clinical Evaluation and Post-Market Surveillance in accordance with new MDR 2017/745 requirements imposes new challenges for manufacturers in medical device industry.

Manufacturers should make clinical evaluation a continuous process that summarizes findings and results from several mutually connected processes: PMS, vigilance, CIs. Gathered clinical evidence should also be used as input for SSCP, PSUR, CEAR.

CIs should be designed, authorised, conducted, recorded and reported in accordance with provisions of Articles 62-81 and Annex XV.

PMS and PMCF activities should provide appropriate evidence of planning, implementation of protocol and reporting; target residual risks and confirm safety and performance over device's lifetime; include activities that address specific questions/residual risks.

All activities are aimed towards several goals: improving quality, safety and reliability of devices and strengthening transparency of information for consumers.

Key words: Medical Device Regulation 2017/745 (MDR), Clinical Evaluation,

Post-Market Surveillance (PMS), Clinical Investigation (CI),

Post-Market Clinical Follow-up (PMCF). 


\begin{abstract}
Abbreviations: MDR: Medical Device Regulation, PMS: Post-Market Surveillance, PMCF: Post-Market Clinical Follow-up, CI: Clinical Investigation, MDD/AIMDD: Medical Device Directive/ Active Implantable Medical Device Directive, CER: Clinical Evaluation Report, SSCP: Summary of Safety and Clinical Performance, PSUR: Periodic Safety Update Report, CEAR: Clinical Evaluation Assessment Report.
\end{abstract}

\title{
Introduction
}

One of the key objectives of the new MDR is to ensure consistently high level of health and safety protection for EU citizens using these products. Making clinical investigation and evaluation requirements more stringent is aimed at improving health and safety through transparency and traceability (1). As expected, the roles of clinical evaluation and clinical investigation become far more prominent under the MDR. Inclusion of MEDDEV 2.7/1 and parts of ISO 14155 into the MDR is to be applauded. Data concerning clinical investigations must be introduced in EUDAMED, as well. The electronic system must also be used for PMCF studies. The design, implementation, and requirements for documentation of a PMCF study have to meet many requirements applicable to clinical investigations (2). All these current requirements represent new challenges for the manufacturers and create future aims for the medical device industry: improving the quality, safety and reliability of medical devices and strengthening the transparency of information for consumers (3).

\section{Clinical evaluation}

In the new MDR 2017/745 great emphasis is placed on clinical evaluation and clinical evaluation related processes as key elements in demonstrating conformity with the relevant safety and performance requirements. Fortunately the manufacturers are not entirely unfamiliar with these processes. Apart from the general principles described in MDD/AIMDD, guidance for performing clinical evaluation could be found in documents such as MEDDEV 2.7.1., ISO 14155:2011 or Declaration of Helsinki. In fact, the main provisions of all these documents are incorporated in MDR (4).

According to MDR, demonstrating conformity with the relevant general safety and performance requirements should be based on clinical evidence provided in accordance with provisions prescribed mainly in Article 61 and Annex XIV.

A clinical evaluation should follow a defined and methodologically sound procedure based on the following points:

(a) a critical evaluation of the relevant, currently available scientific literature relating to the safety, performance, design characteristics and intended purpose of the device, 
(b) a critical evaluation of the results of all available clinical investigations, and

(c) a consideration of currently available alternative treatment options for that purpose, if any.

The clinical evaluation and its documentation should be updated throughout the life cycle of the device concerned with clinical data obtained from the implementation of the manufacturer's PMCF plan in accordance with Part B of Annex XIV and the PMS plan referred to in Article 84. All conclusions should be summarized in the CER (5).

\section{Challenges for manufacturers}

New requirements for the clinical evalaution become mandatory with their inclusion in the Regulation and therefore it is of great importance for the manufacturers to implement and upgrade it in such a way that it's inputs and outputs can be used for as many other related activities.

Manufacturers should make clinical evaluation a continuous process which should summarize the findings and results from several mutually connected processes such as PMS, vigilance, performing of CIs etc., and their output documents, as presented in Figure $1(6,7)$.

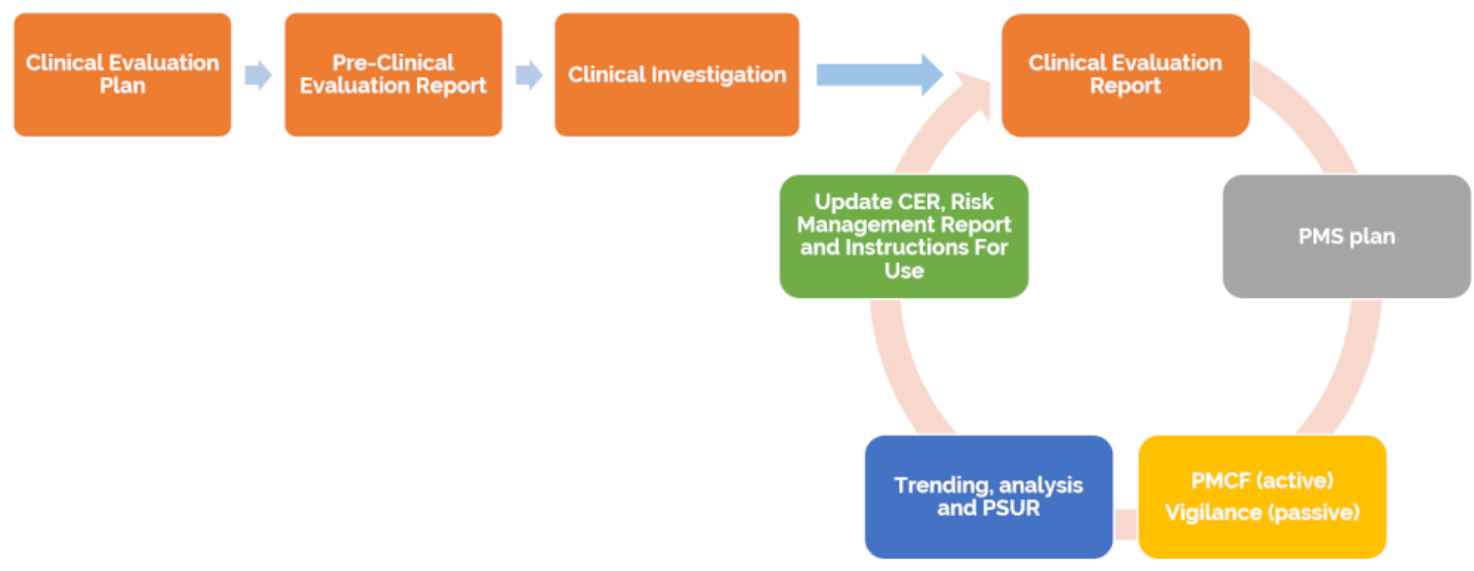

Figure 1. Processes connected with Clinical Evaluation

Slika 1. Procesi povezani sa kliničkom evaluacijom

Gathered clinical evidence should as well be used as an input for assembling SSCP, PSUR, as well as CEAR that will be prepared by Notified Body, as presented in Figure 2 (8). 


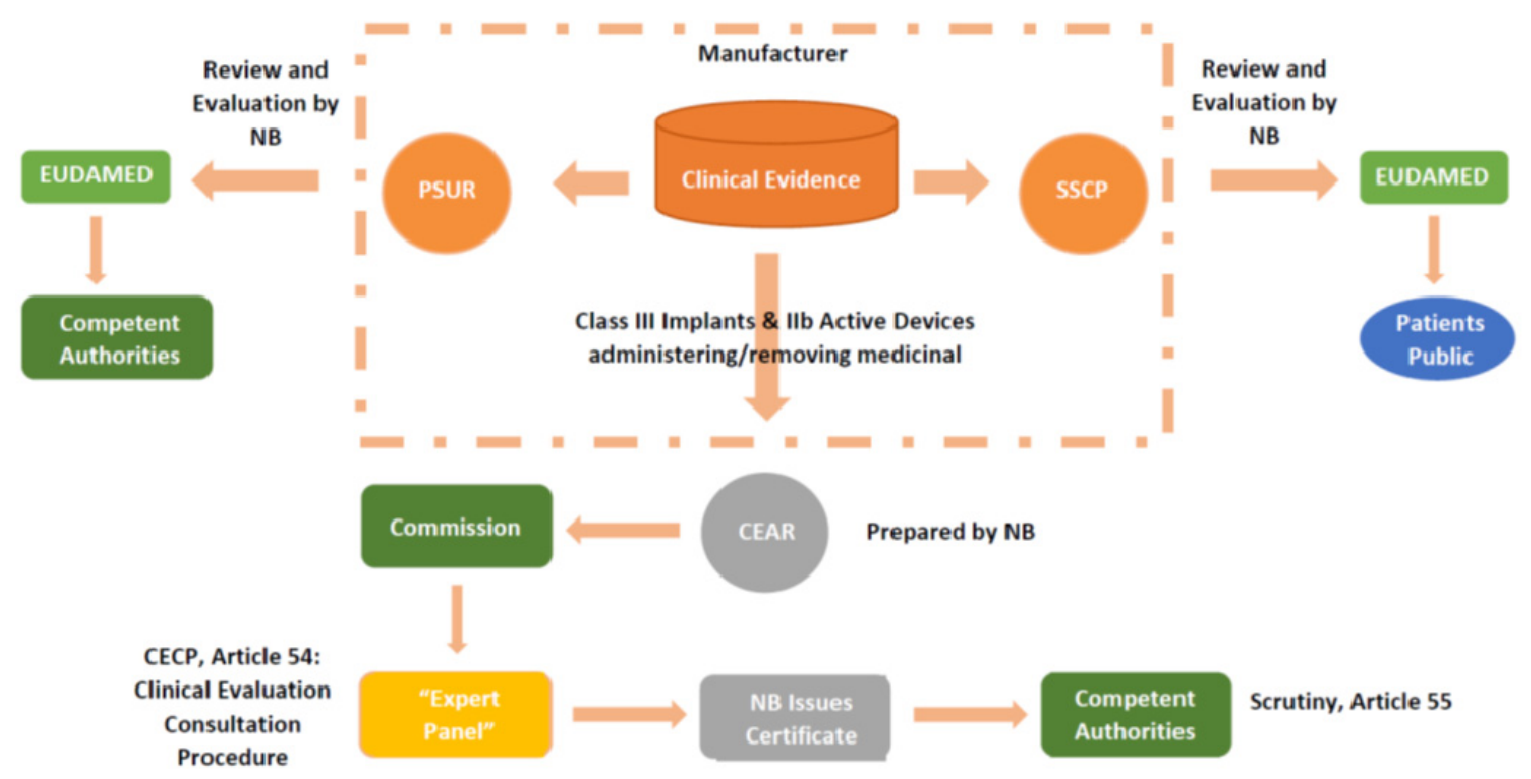

Figure 2. Clinical evidence as input for Clinical Evaluation/PSUR/SSCP/CEAR Slika 2. Klinički dokazi kao ulazni elementi za kliničku evaluaciju/PSUR/SSCP/CEAR

The demonstration of equivalence between devices now presents a great challenge that should also be based on the clinical evaluation and can be achieved by demonstrating that each device with which equivalence is claimed must fulfil all technical, biological and clinical characteristics, as demonstrated in Figure 3 (8). 
MEDDEV 2.7.1 Rev 3 / MEDDEV 2.7.1 Rev 4 / MDR (Annex IV) - Equivalence
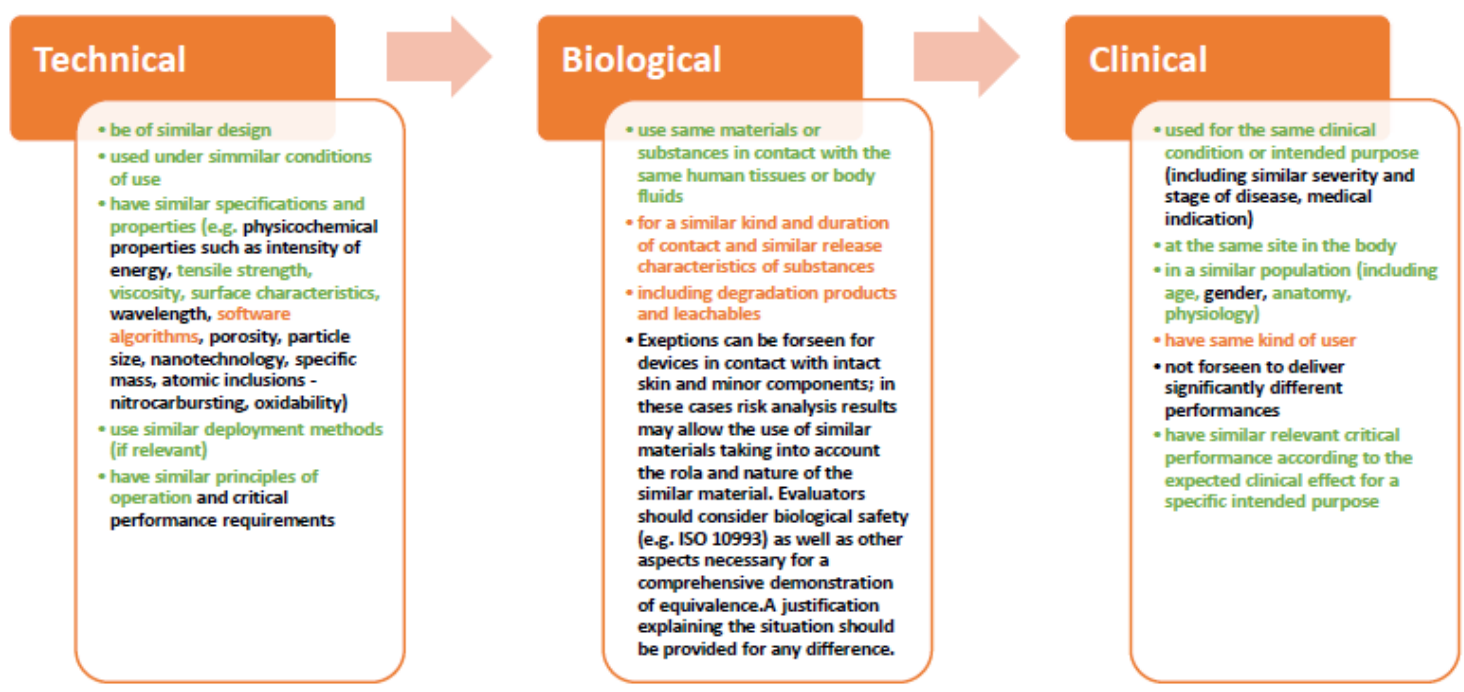

Figure 3. Technical, biological and clinical characteristics for demonstration of equivalence Slika 3. Tehničke, biološke i kliničke karakteristike za dokazivanje ekvivalencije

\section{Clinical Investigations}

CIs shall be designed, authorized, conducted, recorded and reported in accordance with the provisions of Articles 62 to 80 of the MDR 2017/745, the acts adopted pursuant to Article 81, and Annex XV, where carried out as part of the clinical evaluation for conformity assessment purposes, for one or more of the following purposes:

a) to establish and verify that, under normal conditions of use, a device is designed, manufactured and packed in such a way that it is suitable for one or more of the specific purposes in accordance with the definition for medical device, and achieves the performance intended as specified by its manufacturer;

b) to establish and verify the clinical benefits of a device as specified by its manufacturer;

c) to establish and verify the clinical safety of the device and to determine any undesirable side-effects, under normal conditions of use of the device, and assess whether they constitute acceptable risks when weighed against the benefits to be achieved by the device (5). 


\section{Manufacturers' responsibility concerning Clinical Investigations}

Each manufacturer should first define the legal requirements for performing CIs and make an assessment of the necessity for gathering more clinical evidence for their devices. In Article 61, Reg. 2017/745 is stated that CIs are mandatory for all implantable and class III devices. CIs are not mandatory if a new implantable or class III device is equivalent to a device already marketed by the same manufacturer and the clinical evaluation of the latter is sufficient to demonstrate the conformity of the new one. CIs are not mandatory for class III devices already marketed under MDD and for implantable devices like sutures, staples, tooth crowns (full list presented in paragraph 6 of the Article 61), that have sufficient clinical data to demonstrate their conformity. It is important to note that, in the absence of clinical data, a low-risk MD requires a CI. Finally, according to the characteristics of the device, and including low-risk device, post-marketing CIs are requested to confirm, integrate or update existing clinical data, especially to address the safety concerns of the device within the frame of a PMCF (5, 9).

Next step would be to start planning and performing the CI. In this process, manufacturers have a good deal of responsibilities, such as:

- Design of the study

- Clinical Investigation plan

- Informed consent and ethical consideration

- Clear measurable objectives

- Criteria to stop the trial

- Statistical power

- Patient population

- Designation of principal investigator

- Insurance

- Application with ethical committee

- The non-EU manufacturer/sponsor may choose to appoint the Authorized Representative to complete the authorization of clinical investigation to EUDAMED.

- Incident Reporting

- In the event of an incident during the clinical investigation, the reporting as such will need to be determined and performed by the appointed Authorized Representative through the EUDAMED database. 
- Documentation available

- The clinical investigation data (reports) should be incorporated in the technical documentation that has to be kept available by the manufacturer of his appointed European Authorized Representative established within the Union.

- Sponsor (authorized representative) shall notify the competent authorities of the ending of the clinical investigation, and submit a report $(5,10)$.

\section{Post-Market Surveillance and Post-Market Clinical Follow-up}

PMS and PMCF activities are interconnected with the Clinical Evaluation. PMS system is described in the Article 83, with defined activities which will result in creating the 3 most significant documents in the process:

- PMS plan (Article 84, Section 1.1 of Annex III),

- PMS report applicable for Class I devices (Article 85) and

- $\underline{\text { PSUR }}$ (Article 85).

Detailed description of the PMCF is defined in Annex IX Part B with main focus on defining the activities (PMCF plan) for proactive collecting and evaluating clinical data with the aim of:

a) confirming the safety and performance of the device throughout its expected lifetime,

b) identifying previously unknown side-effects and monitoring the identified side-effects and contraindications,

c) identifying and analyzing emergent risks on the basis of factual evidence,

d) ensuring the continued acceptability of the benefit-risk ratio, and

e) identifying possible systematic misuse or off-label use of the device, with a view to verifying that the intended purpose is correct $(5,11)$.

\section{Role of the manufacturers}

The appropriate reinforcement of PMS procedures and data entails:

- Better control of distributors to ensure all PMS data is received from the distributor directly.

- Under the MDR, distributors are economic operators with responsibility for monitoring the devices they put onto the market. 
- The legal manufacturer must ensure appropriate PMS and vigilance actions are undertaken by the distributor under full control and surveillance from the legal manufacturer.

- Ensuring complaints are logged from all sources more effectively and are investigated in a timely and thorough manner.

- More detailed analysis of complaints with a thorough assessment of their impact on the overall clinical safety and performance.

- Trending of PMS data to better understand and identify emerging device concerns.

- Ensuring the PMS data feeds into risk management and is incorporated into the updated CER.

PMCF activities should:

- Provide appropriate evidence of planning, implementation of protocol and reporting with reasonable timelines.

- Target residual risks and confirmation of safety and performance over a device's lifetime, and should not be trying to answer questions that should have been addressed prior to CE marking.

- Include all targeted structured post-market activities that address specific questions/residual risks.

What PMCF is not....

- An expedient route to gain early CE certification and then gather critical clinical evidence later on.

- A post-market study with primary objectives to demonstrate safety and performance requirements which should have been addressed pre-CE marking.

- A token gesture to regulators to follow-up a few patients with an adequate survey that does not provide any meaningful information (12).

\section{Conclusion}

New requirements of the MDR regarding Clinical Evaluation and PMS are aimed towards imposing manufacturers a continuous providing of clinical evidence for the medical devices throughout their lifecycle. This could be achieved by following the provisions related to preparing detailed plans for Clinical Evaluation and PMS activities, clearly defining the process of PMCF, and designing CIs in a manner that will 
ensure and continuously improve health and safety of the users. Electronic databases of EUDAMED will play a great role in providing the necessary transparency and traceability of all manufacturers' activities on this matter by making them publically available.

\section{References}

1. Norbert Clemens, MD, PhD, CPI. The New European Medical Device Regulation 2017/745: Main Changes and Challenges. Clinical Researcher October 2017. DOI: 10.14524/CR-17-0028. 27 p.

2. EMERGO by UL. Evangeline Loh, PhD, RAC (US/EU) Global Regulatory Manager, Ronald Boumans, MsC Senior Global Regulatory Consultant. Understanding Europe's new medical devices regulation (MDR 2017/745) New requirements, key changes, and transition strategies for device companies. July 2018. 14 p.

3. European Commission. New EU rules on medical devices to enhance patient safety and modernise public health. 05/04/2017.

4. Factory CRO for Medical Devices and IVDs [Internet]. Leonie van de Kamer, Clinical Study Manager. Clinical Investigations - What changes because of the Medical Device Regulation?. March 21, 2018. Available from: https://www.factory-cro.com/news/clinical-investigationschanges-medical-device-regulation/.

5. European Commission. Regulation (EU) 2017/745 of the European Parliament and of the Council of 5 April 2017 on medical devices, amending Directive 2001/83/EC, Regulation (EC) No 178/2002 and Regulation (EC) No 1223/2009 and repealing Council Directives 90/385/EEC and 93/42/EEC.

6. EMERGO by UL. Jaap Laufer, MD, PharmD, EMERGO Vice President, Regulatory \& Clinical Affairs. Understanding EU Clinical Investigation Requirements for Devices. July 2017.

7. XENDO a propharma group company [Internet]. Jan Bart Hak. Medical Device Regulation: 4 Steps to prepare your clinical evidence. 22.09.2018. Available from: https://www.xendo.com/news-blog/blog/172-medical-device-regulation-4-steps-to-prepare-yourclinical-evidence.

8. BSI - The British Standard Institution. Suzanne Halliday, D.Phil., Jaishankar Kutty, Ph.D., Ronald Rakos, Ph.D. MDR Risk and Clinical Requirements. October 2017. 30, 36 p.

9. Bianco S, Nunziata A, Pozzoli G. Clinical investigations on medical devices, after the new European regulation (2017/745). Clin Trial Pract Open J. 2017; 1(1): 10-14. doi: 10.17140/CTPOJ$1-102.3 \mathrm{p}$. 
10. OBELIS European Authorized Representative center [Internet]. Clinical Evaluation and Clinical Investigation. Available from: http://obelismedical.net/clinical-evaluation-and-clinicalinvestigation/.

11. EU MDR European Union Medical Devices Regulation [Internet]. Post Market Surveillance compared to the MDD. Available from: http://eumdr.com/post-market-surveillance-compared/.

12. NAMSA - North American Science Associates. Adrian Keene, Director of Product Development Strategy. Leveraging Post-Market Surveillance and Post-Market Clinical Follow-Up Data to Support EU Medical Device Regulation (MDR) Compliance. July 2018. 15-16 p. 


\title{
Obezbeđivanje kliničkih dokaza u skladu sa MDR 2017/745 - novi izazovi za proizvođače $u$ industriji medicinskih sredstava
}

\author{
Elena Ivanovska ${ }^{{ }^{*}}$, Jasmina Tonić Ribarska ${ }^{2}$, Jelena Lazova ${ }^{1}$, \\ Nada Popstefanova ${ }^{1}$, Marija Davčeva Jovanoska ${ }^{1}$, \\ Suzana Trajković Jolevska² \\ ${ }^{1}$ Farmaceutska hemijska kozmetička industrija ALKALOID AD Skopje, \\ Skopje, Republika Severna Makedonija \\ ${ }^{2}$ Farmaceutski fakultet, Univerzitet „Sv. Kiril i Metodij”, Skopje, \\ Republika Severna Makedonija
}

*Autor za korespondenciju: e-mail: eivanovska@alkaloid.com.mk

\section{Kratak sadržaj}

Obezbeđivanje potrebnih kliničkih dokaza kroz sisteme kliničke evaluacije i postmarketinškog nadzora u skladu sa zahtevima regulative MDR 2017/745 nameće nove izazove za proizvođače medicinskih sredstava.

Proizvođači treba da obezbede da klinička evaluacija postane kontinuirani proces koji sumira nalaze i rezultate nekoliko međusobno povezanih procesa: PMS, vigilanca, CIs. Objedinjeni klinički dokazi bi trebalo da budu iskorišćeni kao ulazni elementi za SSCP, PSUR, CEAR.

CIs bi trebalo da budu dizajnirana, odobrena, sprovedena, zabeležena i prikazana u skladu sa zahtevima propisanim u članovima 62-81 i Aneksa XV.

Aktivnosti u vezi PMS i PMCF bi trebalo da obezbede odgovarajuće dokaze o planiranju, sprovođenju protokola i izveštavanja; ciljni rezidualni rizik i potvrdu sigurnosti i performansi za vreme životnog ciklusa medicinskog sredstva; da uključuju aktivnosti koje se odnose na specifična pitanja/rezidualni rizik.

Sve aktivnosti su usmerene u postizanju nekoliko ciljeva: poboljšanje kvaliteta, sigurnosti i pouzdanosti sredstava i jačanje transparentnosti informacija za korisnike.

Ključne reči: Regulativa o medicinskim sredstvima 2017/745, klinička evaluacija, praćenje medicinskog sredstva posle stavljanja na tržište, kliničko ispitivanje, postmarketinško kliničko ispitivanje. 